\title{
Public Interest Litigation (PIL) as Strategic Legal Mechanism on Women's Socio-Economic Rights in Nigeria: Making a Case for Girl Child Education
}

\author{
Olayinka O. Adeniyi, LL.D., BL; LL.M, LL.B \\ QEScholar, Research Fellow, Centre for Intellectual Property and \\ Information Technology Law (CIPIT), Strathmore Law School, Strathmore \\ University, Nairobi, Kenya. CEO, Women on The Watch Society Initiative, \\ South Africa
}

Omolade O. Olomola, Ph.D., BL; LL.M, LL.B

Senior Lecturer, Department of Private and Property Law and Staff

Clinician, Women's Law Clinic, Faculty of Law, University of Ibadan, Nigeria

Doi:10.19044/esj.2020.v16n29p62ＵRL:http://dx.doi.org/10.19044/esj.2020.v16n29p62

\begin{abstract}
The percentage of girl child illiteracy is higher in girls than boys in Africa. This is particularly so in Nigeria. It is trite that Girl-child issues are generally confined within women's right in Nigeria. As important as education is to life and humanity, it however falls under socio economic rights in Nigeria, which by virtue of the interpretation of constitutional provisions are argued as non-justiciable. Hence, accessing education for the girl child as a justice system or mechanism has been a challenge in the country. In recent times, some countries have directed public Interest litigation into fighting some socio-economic issues. This is a development which has not been practiced earlier and success is being recorded. It can be said that Public Interest litigation has been able to deal particularly with the challenge of locus standi which has to do with the opportunity of accessing justice on some rights issues. Focusing on girl-child education in Nigeria, as a socio-economic rights issue to which access to justice is a challenge and to which legal strategic mechanism can bring a change is a positive one. The paper looks at the impact of African girl child illiteracy at this time in the global environment for sustainable development, the legal impediments to accessing justice on socio economic rights; recent legal mechanisms as best practices of getting socioeconomic rights enforced in some developed countries; innovative and emerging ways of its realization and enforcement in Nigeria. It proffers suggestions on legal and strategic litigation introduction or enhancement mechanism, the challenges if any and the gains more importantly of the public
\end{abstract}


litigation procedure. The paper attempts a desktop and library-based approach in a comparative analysis of legal framework, policies on education, literature review of existing scholarship, case study on strategic litigation in some jurisdictions on socio economic rights and applies it to suggest Public Interest Litigation PIL for girl child education in Nigeria. The paper is germane for women's right advancement, law and or policy reform and citizen empowerment in Nigeria and Africa at large.

Keywords: Justice, litigation, strategic, girl-child, education, socioeconomic rights, Nigeria, constitution, mechanism, development, Africa

\subsection{Introduction}

Human rights are the rights which belong to every human by virtue of their being human (Flowers, 1998). This is irrespective of their status, race, creed, sex or age (Marks 2014). The constitutions of many countries contain the bill of rights or what is called fundamental human rights (Chapter iv CFRN, Chapter 2 RSA). These human rights can be argued to have been demarcated into political and civil rights and cultural and socio-economic rights (Ilesanmi, 1997). Socio economic rights are those rights that give people access to certain basic needs necessary for human beings to lead dignified lives (Khoza, 2007). Socio economic rights often regarded as second-generation rights have a relatively short history in many countries of the World (Shehu, 2013). In Nigeria, Socio-economic rights are provided for under the Fundamental Objectives and Directive Principles of State Policy (S16-18, CFRN1999). The fundamental objectives are the ideological foundation of governance in Nigeria. As directive principles, they are in the form of the minimum standard aspiration, which the government must strive to attain (Shehu, 2013). These socio-economic rights house the right to health, food, water, shelter, education and basically the rights that have to do with living a dignified life.

Education is a form of learning through which the knowledge, skills, values, benefits and habits of a group of people are transferred from one generation to the next (Churr, 2015). Education has been described as the most important aspect of human development, a key to successful living (Omede \& Agahiu, 2016). Education, particularly of the girl child is important for nation building and sustainable development (Abbagana, 2013). Girl-child education is the training of the girl to enable her to acquire character development and mental prowess necessary for her to contribute to nation building and function well in her society (Mshelbila, 2012).

However, the objective principles under which the right to education falls are argued to have been rendered non justiciable by virtue of S6(6) of the Nigerian constitution. The argument of justiciability or non-justiciability of 
these rights have been the subject of debate in many intellectual circles (Alisigwe, 2010, Alabi, 2006). This is despite the provisions of other rights like the right to non-discrimination in the constitution which may be argued to strengthen the enforceability of the objective principles. It is trite that general inequality persisting in Africa specifically exposes the female gender to vulnerability and infringement of her rights (Ajala, 2017). This is the case in Nigeria where many challenges confront the realization of girl child access to socio-economic rights particularly with regard to the right to education (Oruonye, 2012). The impact of the African girl child illiteracy is an important issue at both national and global level. The sustainable development goals can be one global approach to improving the situation of girl children and these cannot be achieved without her access to education. Strategic legal mechanisms including strategic litigation and precisely public interest litigation may be a solution to enable the girl child to access the right to education and thus a better future for her and the next generation of the African children. Litigation is a traditional human rights approach, only more recently used specifically for economic and social rights work in regions like South Africa, Argentina and India (Symington et al., 2006). In many countries, citizens have come up innovative measures or strategies of realizing their goals (Adeniyi et al., 2019). The same can be recommended for Nigeria. Law and policy reform to guarantee the rights, research, advocacy, engaging with budget, campaigns and popular mobilisation can be accessed to improve the situation.

\section{An outline of the legal framework for education in Nigeria}

Existing legal framework can be international, regional and domestic. International human rights documents make provisions for the right to education. This can be through treaties and agreements to which states are parties.

2.1 The Universal Declaration of Human Rights (UDHR) provides the right of everyone to basic education which shall be free and compulsory. Technical and professional education shall be made generally available and higher education shall be equally accessible to all by merit (Art 26 UDHR).

The International Covenant on Economic, Social and Cultural Rights ("the ICESCR") provides states obligation to make education available, accessible, acceptable and adaptable (Art 13(2) and 14 ICESCR). The International Covenant on Civil and Political Rights (ICCPR), 1966(Art 18, 19(2) ICCPR). The UNESCO Convention Against Discrimination in Education, 1960. The International Convention on the Elimination of All Forms of Racial Discrimination (ICERD), 1966 (Art 5). The Convention on the Elimination of All Forms of Discrimination against Women (CEDAW) 
1979 (Art 10 CEDAW). The Convention on the Rights of the Child (CRC) 1989. The UN Convention on the Rights of the Child recognises the right of the child to education and makes primary education compulsory and available free to all (Art $28 \mathrm{CRC}$ ). The World Declaration on Education for All Meeting Basic Learning Needs, 1990 Provides that education is a fundamental right for all people, women and men, of all ages, throughout our world. The World Declaration on Education for All (EFA) 1990 stresses learning opportunity for every individual to participate in the process of nation building.

2.2 Regional human rights instruments too provide for the right to education. The African charter on human and peoples Right (Art 17 ACHPR). The African Charter on the Rights and Welfare of the Child, 1990 (African Children's Charter. The African charter on the Rights and Welfare of the Child provides for every child's right to education (Art 11) and for girls (Art 11(3).

In the ECOWAS Community Court case of The Registered Trustees of the Socio-Economic Rights and Accountability Project (SERAP) v. Federal Republic of Nigeria and Universal Basic Education Commission,( $\mathrm{ECW} / \mathrm{CCJ} / \mathrm{APP} / 12 / 07)$ it was held that notwithstanding the fact that the right to education is not justiciable under the Nigerian 1999 Constitution; the Court can enforce the right to education as provided for under Article 17 of the African Charter. The Court further held that the plaintiff has locus standi to initiate and maintain this suit.

2.3 As an important aspect of every society, there exists legal framework and policies for education in countries. The provisions for education could be found in specific documents on education. As a basic right, education is provided in the bill of rights or within constitutions of many countries (Churr, 2015).

The Constitution of the Federal Republic of Nigeria 1999 in S18 provides the educational objectives of the government. "Government shall direct its policy towards ensuring that there are equal and adequate educational opportunities at all levels and that: (2) Government shall promote science and technology. (3) Government shall strive to eradicate illiteracy; and to this end Government shall as and when practicable provide: (a) free, compulsory and universal primary education..."

Apart from the Nigerian constitution, the Child Rights Act in Nigeria provides for the right to education. Policies on education also exist as part of the legal framework for education in Nigeria. Nigeria's policies on education are made pursuant to Section 18(1) of the Constitution of the Federal Republic of Nigeria 1999. The National Policy on Education is a specific education policy which provides for the right to education in Nigeria. S2(11) of the 
Policy provides for Universal basic education in its objectives: a) Developing in the entire citizenry a strong consciousness for education and a strong commitment to its vigorous promotion; b) The provision of free, universal basic education for every Nigerian child of school age; c) Reducing the incidence of drop-out from formal school system, through improved relevance, quality and efficiency; d) Catering through appropriate forms of complementary approaches to the promotion of basic education, for the learning needs of young persons who for one reason or another have had to interrupt their schooling; and e) Ensuring the acquisition of the appropriate levels of literacy, numeracy, communicative 'arid life' skills/as well as the ethical, moral, security and civic values needed for the laying of a solid foundation for lifelong learning.(NPE 2013)

S1(3) National Policy on Education provides that a) Education is an instrument for national development and social change; b) Education is vital for the promotion of a progressive and united Nigeria; c) Education maximizes the creative potentials and skills of the individual for self-fulfilment and general development of the society; d) Education is compulsory and a right of every Nigerian irrespective of gender, social status, religion, ethnic background and any peculiar individual challenges; and e) Education is to be qualitative, comprehensive, functional and relevant to the needs of the society(NPE 2013).

This basic education is guaranteed by the government to be free, compulsory, universal and qualitative. It spreads across 1 year of Kindergarten; 6 years of primary; and 3 years of Junior Secondary Education' (NPE 2013).

\section{Socio economic rights vis a vis right to education under the Nigerian Constitution}

Socio economic rights are those rights that serve the purpose of ensuring that human beings can obtain and maintain a minimum decent standard of living that is consistent with human dignity (Conde, 2004). These rights include the right to health care, food, work, water, social security, education, shelter and highest standard of living (Ezechukwu, 2017). The Nigerian constitution provides for the right to freedom of expression as a fundamental human right (Chapter iv CFRN 1999). While this right to freedom of expression includes access to and entitlement to give and receive information,(S39 CFRN 1999) which can be subsumed as the right to education, the actual right to education is provided under chapter 2 of the Nigerian constitution (S18 CFRN 1999). This chapter 2 of the constitution, however, provides for the ideals and objectives of the government, not fundamental human rights, and this is where the socio- economic rights are sited (S13-24 CFRN 1999). While the fundamental rights in chapter 4 are 
justiciable and can be enforced in the courts of law, the contents of chapter 2 being ideals and government aspirations are argued not justiciable. The nonjusticiable is from the interpretation of the provision of S6(6) of the Constitution.

Now linking the right of girl child education to the fundamental human rights to dignity, to non-discrimination and to freedom of expression as to receive and give information, the argument of the non- justiciability of right to education as a socio-economic right becomes confusing.

However in the case of Olafisoye v Federal Republic of Nigeria [2004] 4 NWLR (pt 864) 580 659), where the Supreme Court held that the nonjusticiability of section $6(6)(c)$ of the Constitution is not sacrosanct, as the section provides a headway by the use of the words 'except as otherwise provided by the Constitution'.

In analysing the provisions of the Nigerian constitution from the provisions of right to education as state objective and directive principle and its non- justiciability, the difficulty in enforcing or the realisation of this right can be observed. However when compared with another constitutional provision on legislative duties, it can be argued that the constitution provides that the judiciary has the responsibility to regulate federal authorities to ensure the observance of fundamental objectives and directive principles of state policies if the legislators create the necessary institutions by law (Item 60(a) CFRN 1999).

\section{The challenges of girl-child education in Nigeria}

There are many challenges to girl child education in Nigeria. These range from legal to educational to socioeconomic, traditional and socio cultural. First among the legal is Constitutional lapses. The Constitution of the Federal Republic of Nigeria 1999 is not specific on girl child education. Educational objectives as enshrined in Section 18 of the Constitution are surrounded by controversies of justiciability. This is from the interpretation of constitutional provision(S6(6) CFRN 1999). Chapter II deals with fundamental objectives and directive principles of State policy, which are not enforceable against the State by Nigerian citizens (Ekhator, 2014). Again, the issue of locus standi in the Nigerian constitution is a clog in the wheel of socioeconomic rights (Olowu, 2009). Locus standi is about the cause of action or the right to be heard before a court of competent jurisdiction. It entails the legal capacity to institute proceedings in a court of law or tribunal, on behalf of another person, the public and or challenge government actions/violations of human rights (Okeke, 2014). This is as interpreted by the constitutional provision that only someone whose right has been infringed or is about to be infringed that has a right of hearing before a court of law. (S46(1) CFRN 1999). However, a new rule of Court has been provided which provides that 
no human rights case should be struck out or dismissed on the grounds of want of locus standi. (S3(e) Fundamental Rights (Enforcement Procedure) Rules 2009). The legal challenge of non-justiciability also happens to be contravened by another provision in the constitution (S6(6)(C)CFRN 1999) which connotes that courts are empowered to enforce directive principles and objectives of state policy if legislative enacts laws and create institutions to that effect.(Item 60, Second Schedule CFRN 1999). Despite the provisions of the fundamental Rights (Enforcement Procedure) Rules 2009 the provision of the supremacy of the constitution over and above every other law or legal provision is another militating argument. (S1(3) CFRN 1999). Other legal challenges can be subsumed under conflict of laws, archaic laws, lack of Proper Policy Implementation and non-existence institutions and systems to improve the situation. Corruption and lack of political will which affect implementation of policies are also factors to be considered as challenges (Okoroma, 2006). Also, the reluctance of the judiciary to use innovation in the interpretation of laws is a challenge too (Ibe, 2007).

Education challenges will include accessibility of schools, security for girls in accessing schools, (Tyoakaa et al, 2014; Oroworukwo, 2014) inclusive of high level of illiteracy and ignorance on the part of parents, guardians and society on the importance of education for all especially for the girl child (Oruonye, 2012).

Poverty is a major challenge which affects the issue of cost and gender norms, stereotypes, religious beliefs, (Ifijeh \& Odaro, 2011). The practice of child marriage (Adeniyi, 2017) and such related issues which fall under Sociocultural challenges are also relevant.

\section{The impact of African girl child illiteracy on global sustainable development}

Education is very important in life (Al-Shuaibu, 2014). Without the right to education, it is difficult to effectively exercise civil rights, to express an opinion and to make a submission. Women and girl child education is a road to development through many routes. Education of the girl child leads to gender equality and social justice, improved skills, technological knowledge acquisition, improved nutrition, access to reproductive health, and economic empowerment. Educated girls mean educated mothers and this translates to their survival, well-being and that of their children (Omede \& Agahiu, 2016). The Sustainable development goals provide that education for women and girls is particularly important to achieve basic literary improve participatory skills, abilities, and improve life chances (Goal 5). Sustainable development is not possible where women and girls are not educated (Nmadu et al, 2010). Education for girls enhances economic productivity and growth. In fact, there is no investment more effective for achieving development goals than 
educating girls (Worldbank, 2017). Education can make a critical difference to a range of health issues, including early mortality, reproductive health, spread of disease, healthy lifestyles and well-being (Goal 3). In addition, education is a powerful instrument that enables women to ac-cess a variety of opportunities, while rendering them less vulnerable to HIV/AIDS, abuse, and exploitation (Worldbank, 2017). Lifelong learning builds capacity to understand and promote sustainable development policies and practices (Goal 17). Education is an instrument to sustainable development (Aroyo, 2018) and also the mechanism for individuals to lead sustainable development as agents of change (Leicht et al, 2018). Improving basic female education has a powerful influence on maternal and infant mortality, morbidity as well as on fertility (Nmadu et al, 2010). Girls' education is a strategic development priority. Better educated women tend to be healthier, participate more in the formal labour market, earn higher incomes, have fewer children, marry at a later age, and enable better health care and education for their children. All these factors combined can help lift households, communities, and nations out of poverty (World bank, 2017). Denying the girl-child access to education implies making her a dysfunctional member of the society (Ifijeh \& Odaro, 2011). Education for the girl child will affect individuals, societies even the natural environment. The benefits of girl child education for sustainable development are improvement of the quality of people's lives, acceleration of economic growth, harnessing of human intellect and potentials, realization of political stability, appreciation of tolerance and the institution of peace and unity (Abbagana, 2013). Uneducated girls easily slip into the margins of societies; ending up less healthy, less skilled, with fewer choices, and remain ill-prepared to participate in the political, social and economic development of their communities. As undereducated women, they will remain at higher risk of poverty, maternal mortality, child mortality, HIV/ AIDS, sexual exploitation, and other forms of violence (Nmadu et al, 2010). The results are poverty, persistent gender inequality, lower standard of living and such related ills.

\section{Best practices and Emerging ways of the realization of socio- economic rights}

Girl-child education is dependent on the realization of the socioeconomic rights of all without derogation. The international Covenant on Economic Social and Cultural Rights (ICESCR) was acceded to by the Nigerian Government on the $29^{\text {th }}$ of July, 1993. This makes it imperative for the government to apply and enforce the contents of the Articles contained in the Covenant. The accession was done without any derogations or objections. This instrument being one of the core nine (9) Human Rights treaties covers a wide range of issues amongst which are the right to work; fair remuneration; 
right to education; right to cultural life amongst others. Economic, Social and Cultural (ECOSOC) rights are the privileges which human beings require to live a life of dignity. These rights presuppose an adequate standard of living, right to physical and mental health and access to social security. Social rights are based on the theory of social contract (Internet Encyclopedia of Philosophy. https://www.iep.utm.edu/soc-cont/). This stems from the fact that human beings are referred to as social animals that simply depend on the society for food, protection, education and other comforts (Olowu, 2017). Social contract theory, nearly as old as philosophy itself, is the view that persons' moral and/or political obligations are dependent upon a contract or agreement among them to form the society in which they live. As a legal order, the society must provide some general needs which are primary in nature (Olowu, 2017). Olowu (2017) in his treatise on Province of Law, Society and Development reiterated the point that human beings are social animals where he stated;

Human beings as social animals cannot live alone in a society and also cannot fulfil all their needs without the help of others.... man needs the society for his very existence or survival.

ICESCR makes provision for education of dependent children and a right to education for everyone under Articles 10 and 13, thus there is a general legal backing for the enforcement of the rights. Notwithstanding the provision of the law on the need for ECOSOC rights, the argument on its justiciability as rights worthy of protection is still raging. The ambiguity created by the various interpretations of these rights is a major challenge for the enforcement. It would be rather incorrect to assume that the Government must build houses for its citizens and force them to go to school (Nwatu, 2013). Proper interpretations of the rights are germane for enforcement.

Apart from the provisions of ICESCR, both the African Charter on Human and Peoples' Rights (AFCHPR), and the Fundamental Objectives and Directive Principles of State Policy enshrined in Chapter II of the 1999 Constitution of Nigeria expresses these rights. It is important to state that Chapter II of the Constitution is rather considered non-justiciable or rather that the enforcement is dependent on the capability of the Government of the day. A major argument in support of the enforcement of the rights is the fact that the African Charter has been domesticated in Nigeria and thus provides a readily available platform for the enforcement of those rights. However, the debate on the gains of socio-economic rights will continue to rage because of the un-abating gross gender inequalities and social imbalances.

The Republic of South Africa has taken the lead by establishing socioeconomic rights in their Constitution and enforcement of same. The case of 
Government of the Republic of South Africa v Grootboom (2000) ZACC 19) buttresses this fact.

Meanwhile Nigeria as a country is yet to take a definite step in that direction. It is clear that Nigerians cannot survive merely on the inclusion of socio-economic rights in Chapter 2 of the Constitution which are fundamental objectives and directive principles of state policy, that are made nonjusticiable unless and until the legislature enacts laws for the enforcement of any aspect of the fundamental objectives. Civil and political rights are components of the fundamental human rights enshrined in chapter 4 of the Nigerian Constitution. The domestication of the African Charter on Human and People' Rights (ACHPR) as African Charter on Human and Peoples' Rights (Ratification and Enforcement) Act, Cap. A9, Laws of the Federation of Nigeria, 2004 provides a good avenue of enforcing socio-economic rights. In the case of Abacha v Fawehinmi (2001,51 WRN) the Supreme Court held that the provisions of the ACHPR have become part of the Nigerian domestic law and therefore justiciable in Nigeria. In furtherance of this position, the provision of Chapter 2 of the Constitution is a major clog for the realisation of socio-economic rights in Nigeria. This provision shut down every available opportunity to redress the anomalous situation of its non-justiciability. There is however a 'green light' for the enforcement of these rights through the decision of the ECOWAS Court in the case of Socio-Economic Rights and Accountability Project (SERAP) v. Federal Republic of Nigeria and Universal Basic Education Commission (ECW/CCJ/APP/12/7). The judgment in this case is a step in the right direction of accountability for the socio-economic rights in Nigeria. In this case the ECOWAS court held that, if the right to education (a socio-economic right) was arguably non-justiciable in domestic constitutional or statutory law, it is justiciable under Article 17 of the ACHPR. The court relied on Article 9(4) of the Supplementary Protocol to the treaty establishing the Court and Article 4(g) of the Revised Treaty of ECOWAS to the effect that "it is well established that the rights guaranteed by the African Charter are justiciable before this Court." Hence, it can be concluded that social and economic rights are recognized and should be enforceable in Nigeria because the country has obligation to ensure compliance to the decisions made by the Courts.

Looking at the challenges of girl child education in Nigeria despite the opportunities explained above, it will take more than mere political will of the government to address the issue. Other strategic actions of judicial activism, and practices like Public Interest Litigation (PIL) and class actions must be taken to correct the inequality and gender imbalances. 


\section{Judicial attempts in Nigeria to enforce socio-economic rights}

Judicial activism has a chequered history right from the United States courts up to the position of activist judges in Nigerian courts (Iman, 2015). Cases on sexual and reproductive health rights which fall under socio economic rights have buttressed the existence of judicial activism in the US. The decision in Cases such as Lawrence v. Texas (539 US 558 (2003), United States v. Morrison (529 US 598 (2000) , Brown v. Board of Education of Topeka (347 US 483 (1954) the very popular Roe v. Wade (410 US 113 (1973) and United States v. Lopex (514 US 549(1995) can be cited as good examples of Judicial activism in the United States Courts. The case of Lawrence v. Texas struck out the Sodomy Law in Texas and by proxy invalidated sodomy law in some other states where they remained, thereby making same-sex sexual activity legal in every states and territories of the nation. This was a Landmark decision of the United States' Supreme Court. The case was based on the Texas Law, which classified consensual adult homosexual intercourse illegal. The US Supreme Court had previously addressed the issue in 1986 in the case of Bowers v. Hardwick (478 US 186 (1986) 149) where the challenged Georgia statute not finding a constitutional protection for sexual privacy was upheld. Lawrence's case explicitly overruled Bower's, holding that it had viewed the liberty interest too narrowly (Imam, 2015). The ground-breaking decision of the court in Roe v. Wade dealt with the issue of abortion and the reproductive rights of women. In Topeka's case United States Supreme Court made a Declaration that State Laws establishing separate public school for black and white students was unconstitutional and the case overruled the 1896 decision of the court in Plessy v. Ferguson (163 US 537 (1896) allowing separate but equal segregation facilities on public transportation were constitutional. If an attempt is made to group all the rights sought before the United State Supreme Courts, socio-economic rights would take the lead. For instance, the issue of equal opportunities for education in Schools, in addition, there is also the enforcement of reproductive rights and sexual privacy. Socioeconomic benefits have never been released on a platter of gold because of the huge responsibility it demands from the government. Thus, recourse to public interest litigation through the court and activities of forward-looking judges will push for its enforcement. The court is a very important tool for the enforcement of socio-economic rights. Apart from the constitutional role of the courts in interpretation of the law, they also make the law through judicial activism (Irons, 1988). Nigeria judiciary is not left out in the struggles to realise socio-economic rights.

The concept or the practice of judicial activism has been used regularly in Nigeria's legal and judicial lexicon for some years. Justices Oputa and Eso were the two judicial activists at the forefront of the campaign that canvassed for Nigerian judges to wear the garb of activism (Elemuo, 2008). Late Oputa 
JSC (rtd.) provided what can be referred to as the correct interpretation of the concept of 'judicial activism' in the case of Aliu Bello V.A.G Oyo State( (1986) 5 NWLR (pt. 45) 528 at 886), where he said that "the spirit of justice does not reside in forms and formalities nor in technicalities nor is the triumph of the administration of justice to be found in successful picking of one's way between pitfalls of technicality." In the same vein, Late Eso JSC (rtd) stated in Trans Bridge Co. Ltd V. Survey Mgt. Ltd (1986) NWLR (pt. 37) 576 at 596597 ), that "it would be tragic to reduce judges to a sterile role and make an automation of them. It is the function of judges to keep the law alive, in motion, and to make it progressive for the purpose of arriving at the end of justice." According to both jurists, judgement of the courts should meet the socio-political and economic events of the times. Where adherence to formality and technicality will not meet the required justice of the matter, the judge is duty bound to distinguish the precedent from the present matter (Elemuo, 2008).

Several activists like the late Constitutional Lawyer Chief Gani Fawehinmi SAN, Femi Falana, Olu Onagoruwa, Ebun Olu-Adegboruwa and some not for profit organisations like Socio-Economic Rights and Accountability Project (SERAP), Campaign for Democracy (CD) and many others have been involved in one way or the other with the enforcement of socio-economic benefits(Adam, 2009).

Judicial activism in public interest litigation is one of the absolute tools for good governance, quality and responsive leadership and accountability in governance.

Many public interest cases have, however, been lost or dismissed in the past as a result of some limitations and challenges to the realisation and successful prosecution of public interest cases. A particular issue is that of locus standi, which is the special interest or losses suffered by the person suing the government or any agency of government to challenge any decision or act of those in government. The judiciary plays a key role as social activist in the Nigerian progressive democratic reality. It is important to note however that judicial activism is usually very rampant during the period of military rule. The reason for this is not far-fetched, the military rules with force and the rule of law is usually suspended.

Judicial intervention is limited by virtue of the legal order in Nigeria and the three (3) arms of government try to play their parts with minimal interference and as usual the executive is always in charge.

In line with provisions of section 6(6) of the Nigerian Constitution, the judiciary exercise vast powers of judicial review from which judicial activism has evolved in respect of the legislative and executive functions. The judiciary as represented by Courts not only act as the third independent arbiters and umpire to determine disputes that may arise between the federal and states but 
also protect and enforce the fundamental rights of the citizens against the arbitrary action of the states.

\section{Adoption of the Public litigation procedure}

Public Interest Litigation (PIL) is an action taken before the court of law for advancement of social welfare. The use of the word "interest" in the world of law refers to "the right material or moral interest protected by law." At other times, it refers to a "beneficial interest or practical that is accrued to the prosecutor of the judgment which is based on his demands (Al-Shabatat \& Al-Kasabeh, 2017). Late Chief Gani Fawehinmi took several writs on behalf of the less privileged in the society (Fawehinmi v. Akilu (1997) NWLR (Pt. 65) Abraham Adesanya v. The President (1981) ANLR 1) This procedure is the legal means of redirecting the focus of the government to the needs of the under privileged in the society. Public Interest Litigation evolved over the years in Nigeria through the efforts of human rights activists which are involved with public lawyering. At the onset there were several critical issues like the concept of locus standi. The issue of locus standi stipulates the legal standing and authority of the person issuing the writ of summons on behalf of another. It is a clear-cut retreat from the traditional legal proceedings (Harshit et al, 2018). The procedure has passed through different challenges before its final recognition.

The commitment of Public Interest Litigation is basically in terms of access to justice. This is in order to make the important fundamental rights realisable for the deprived and vulnerable group of community. The deprived are given hope of getting their rights respected. Public Interest Litigation Public Interest Litigation (PIL) is a legal mechanism through which individuals, groups of people and communities contest government decisions and challenge social justice. It is done for the protection of collective interests. Issues of social and economic imbalance are challenged through PIL and it is often adopted as a strategy in support of the less privileged and the vulnerable in the society. Access to justice can be affected by indigence, thus PIL provides a veritable avenue to commence litigation against mistreatment and deprivation of social and economic resources (Khatthewale 2016).

Human rights and justice are intertwined and very vital for the development of the society. The purpose of the law is the maintenance of law and order and to do justice between members of the society without any derogation. Without the observance of the rule of law, the country would be set on a path of obliteration. Access to justice for all is germane because the end of law is equality, fairness and justice (Angwe, 2017). In the case of $R v$ Sussex Justices, Ex parte McCarthy (1924] 1 KB 256, [1923] All ER Rep 233); Chief Justice Hewart stated..."It is not merely of some importance, but of 
fundamental importance that justice should not only be done, but should be manifestly and undoubtedly seen to be done."

It is therefore submitted that adherence to human rights principles is germane to obtaining justice and should be protected in all instances. It has been asserted that to be able to expand the horizon of human rights, it is very important to test the rights of a group of people collectively in the court of law (Jaichand, 2004). The internalisation of both international and regional human rights standards through enforcement in a domestic legal system is the building block for PIL.

\subsection{The pros and cons of public litigation procedure}

In Nigeria, public interest litigation has been used as a tool to effect change and influence legal development. It thus, fulfils the mandate of law as an instrument of social engineering. PIL expands the concept of access to justice and it helps in the improvement of the law in terms of the governed. It is anchor for the less privileged and the vulnerable members of the society.

The gains of PIL include but not limited to the following:

1. It applies pressure on the government for accountability. This would enhance performance since government agencies are aware of its monitoring.

2. Public interest litigation provides broader access to justice. Through the use of test cases in class actions, PIL is used to stimulate law reforms which have overall positive effect on large numbers of people (Temidayo, 2013).

3. It supports the government by provision of resources for the monitoring and enforcement of infractions against the law.

4. It is an avenue for law making through judges' pronouncements. It further helps to clarify ambiguities in the law and improve human rights protection.

5. The practice is complementary to the criminal justice system.

6. It is an opportunity to remedy deep seated discrimination and injustices suffered by vulnerable individual, groups and communities (Khetthewale, 2016).

7. Through public interest litigation, the courts are urged to validate or redefine rights in constitutions, statutes, and treaties to better address the wrongdoings of government and society and to help those who suffer them.

8. PIL help the courts to validate and make pronouncements on rights hidden in the laws to correct illegalities on the part of the government and aid the deprived (Temidayo, 2013). 
9. In Nigeria, public interest litigation has been used as a tool to effect change and influence legal development, notably by Chief Gani Fawehinmi SAN. A foremost forensic lawyer and ingenious legal mind, he, more than any individual, has stamped his influence on the public interest litigation terrain in Nigeria.

8.2 PIL with all the acclaimed advantages possesses some demerits which must be discussed alongside the merits. The following are considered as the demerits of the PIL procedure (Khatthewale, 2016).

1. PIL may be subjected to abuse by individuals or groups to further their personal or commercial interests;

2. PIL may (if adequate care is not taken) lead to a large number of complex, long lasting cases which can 'clog up' the legal system and create substantial costs;

3. PIL give judges wide discretion in interpreting and defining the public interest which, arguably, could violate the separation of powers doctrine. In addition, when power is absolutely given, it will always lead to abuse and misuse. Positive law making through the legislature will be a better alternative in this wise.

4. PIL may be constrained through existing law which often does not reflect the current actual circumstance in reality;

5. PIL procedure may leave public interest litigants that are unsuccessful with an obligation to pay the often-substantial costs of the state and other parties. Recently in Nigeria, a popular Human Rights activist Femi Falana SAN made an outcry on the punitive issuance of costs against PIL litigants and the lawyers representing them before the court. (Adesomoju, 2019).

He stated that ...

"With respect, the renewed attack on public interest litigation by judges cannot be justified under the Constitution and the African Charter on Human and Peoples Rights (Ratification and Enforcement) Act. Specifically, the Fundamental Rights (Enforcement Procedure) Rules 2009 have enjoined judges to encourage public interest litigation in promoting the human rights of Nigerian people. "Ex abundanti cautela, the doctrine of locus standi has been abolished in the area of human rights by Order III of the Fundamental Rights Enforcement Procedure Rules 2009. Since access to court has been guaranteed by Sections 6 and 36 of the 
1999 Constitution and article 7 of the African Charter on Hunan and Peoples Rights Act it is illegal and unconstitutional to impose fines on aggrieved citizens who approach the courts to challenge the illegal official policies or unconstitutional legislations under the current democratic dispensation." Reminding judges of Supreme Court's decision, Falana said judges should desist from striking out or dismissing cases challenging impunity of public officers in Nigeria.

6. PIL depend heavily on the lawyers involved and the financial backing of parties and this affects the outcome which brings about judgments that lacks enforcement.

In all, it takes the combined efforts of citizens and government to achieve economic growth in countries (Al-hosban \& Edienat 2017). This is inclusive of the empowerment of the girl child and the fight for her socioeconomic rights through the right to education. Public interest litigation and litigants have been and will remain central to holistic change strategy. This can be achieved where are legal minds who can see it and use it as a tool to effect social change. This flows from the premise that those who exercise the rule of law have the obligation to protect the freedoms and human rights of the citizens (Skenderaj, 2015).

\section{Conclusion}

Concluding in the word of the late Sage Nelson Mandela (WHO, 2002), "safety and security don't just happen; they are the result of collective consensus and public investment. We owe our children, the most vulnerable citizens in our society, a life free of violence and fear."

The focus of every government especially in the developing countries should be child and the adolescent population. With the spate of violence against the female sex particularly young girls, they are gradually getting into a category of endangered species because of what they are exposed to, every day. Some of the challenges being faced by the girl child include but not limited to sexual assault, gender discrimination, early marriage, unwanted pregnancy, illiteracy and trafficking. The concept of education is the process of providing information to an inexperienced person to help him or her develop physically, mentally, socially, emotionally, spiritually, politically and economically. According to Ocho,(2005) education is the process through which individuals are made functional members of their society It is a process 
through which an individual acquires knowledge and realizes his or her potentialities and uses them for self-actualization, to be useful to herself and others. It is a means of preserving, transmitting and improving the culture of the society. In essence, when a child is trained, he or she is liberated, and the total person is improved. Thus, education is a fundamental human right which everyone should have access to irrespective of age, sex and nationality. Confining the girl-child to the kitchen destroys their God-given talent and keeps them in perpetual darkness. In addition, obtaining quality education is the foundation to creating sustainable development. In furtherance of this, quality education is the fourth sustainable development goal. The mission of this goal is to ensure inclusive and equitable quality education and promote lifelong learning opportunities for all. The enormity of the situation of the girl child in Nigeria cannot be over emphasized as over one-third are out of school (Philips, 2019) and there seem to be apathy on part of the government. It is thus recommended that the government give life to the right for education as provided in the African Charter (African Charter on Human and Peoples' Rights (Ratification and Enforcement) Act Chapter A9 Laws of the Federation of Nigeria 2004). and enforce the provisions of the Child Rights Act (Child's Rights Act 2003, Chapter C50, Laws of the Federation of Nigeria 2004) against early marriage and girl-child abuse. As a strategic legal mechanism, individuals and groups are encouraged to make use of PIL as one means of helping and promoting the socio-economic right of the girl child to education.

\section{References:}

1. Abbagana, KK (2013) 'Female-Child Education: A Critical Issue for National Development in Nigeria' 5(2), Journal of Education and Leadership Development, 5.

2. Adam, A (2009) 'Nigeria: Judicial Activism and Public Interest Litigation' Daily Independent Newspaper (Lagos) accessed on 28082019.

3. Adeniyi, EK; Eneji, RI; Okpa, JT (2019) 'Unemployment and Drug Trafficking Among Suspects in Custody of the National Drug Law Enforcement Agency, Cross River State Command, Nigeria' 15(19) European Scientific Journal, 194.

4. Adeniyi, O (2017) 'Legal Protection of the Girl child against Child marriage (Aure Yarinya) in Nigeria' LLD Thesis University of Pretoria, South Africa.

5. Adesomoju, A (2019) 'Falana criticises fines on public-interest litigants, lawyers' The Punch Newspaper published June 3, 2019. Accessed via https://punchng.com/falana-criticises-fines-on-publicinterest-litigants-lawyers/ 27082019. 
6. Ajala, T (2017) 'Gender discrimination in land ownership and the alleviation of women's poverty in Nigeria: A call for new equities' 17(1) International Journal of Discrimination and the Law

7. Alabi, MOA (2006) 'Fundamental Objectives and Directive Principles of State Policy' The Jurists 77-82

8. Alisigwe, H (2010) 'Towards the Justiciability of Chapter Two of the 1999 Constitution' 3:1 Journal of Public Law and Constitutional Practice 39-49

9. Al-hosban, S; Edienat, M (2017) 'The Validity of Okun's Law, Case of Jordan' 13(28) European Scientific Journal 471

10. Al-Shabatat, MA; Al-Kasabeh, HHS (2017) 'Interest Clause in the Constitutional Lawsuit in Accordance to the Constitutional Court in Jordan' 13(1) European Scientific Journal 262

11. Al-Shuaibi, A 'The Importance of Education' Research gate 2014 at https://www.researchgate.net/publication/260075970_The_Importanc e_of_Education accessed 30 August 2019

12. Angwe, B 2017 "Access to Justice and Protection of Rights of Citizens" Paper Presented At A Session of the Refresher Course For Magistrates On Modern Judicial Practice And Procedure-Modernising Judicial Practises And Procedures, Held At The Andrews Otutu Obaseki Auditorium, National Judicial Institute, Abuja 24th-28th April, 2017

13. Aroyo, C 'Educating Girls, The Only Road to Achieve the SDGs' A Report Inter Press Service 26 Jul 2018 at https://reliefweb.int/report/world/educating-girls-only-road-achievesdgs accessed 29 August 2019

14. Churr, C (2015) 'Realisation of a Child's Right to a Basic Education in the South African School System: Some Lessons from Germany' 18(7) PER/PELJ

15. Conde, H (2004) 'A Handbook of International Human Rights Terminology' Lincoln, Nebr: University of Nebraska.

16. Ekeke, A (2014) 'Access to justice and locus standi before Nigerian courts' LLM Dissertation University of Pretoria.

17. Ekhator, E.O (2014) 'Improving Access to Environmental Justice Under the African Charter on Human and Peoples' Rights: The Roles of NGOs in Nigeria' 22(1) African Journal of International and Comparative Law 66

18. Elemuo, C (2008) 'Nigeria: Judicial Activism as Amplifier of Justice (1)' Daily Independent Newspaper of December 3, 2008. Accessed on 30082019 via https://allafrica.com/stories/200812040136.html 
19. Ezechukwu, PO 'Critique of socio-economic rights provisions under chapter 2 of Nigerian constitution and their justiciability' 2017 LLM Dissertation, University of Pretoria

20. Flowers, N 'Human Rights here and Now Celebrating the Universal Declaration of Human Rights' 1998 at http://hrlibrary.umn.edu/edumat/hreduseries/hereandnow/Part1/short-history.htm accessed 30 August 2019

21. 'Girls education' The world bank at https://www.worldbank.org/en/topic/girlseducation accessed on 29 August 2019

22. Harshit, S. Jain; Sundaram A; (2018) 'A Study on the Advantages and Disadvantages of Public Interest Litigation' International Journal of Pure and Applied Mathematics 120(5) 4469-4479 accessed on 25082019 http://www.acadpubl.eu/hub/ Special Issue

23. Ibe, S (2007) 'Beyond Justiciability: Realising the promise of socioeconomic rights in Nigeria' 7 African Human Rights Law Journal

24. Ifijeh, GI; Odaro, O (2011) 'Issues in Girl-Child Education in Nigeria: Implications for Library and Information Support' 9(2) Gender \& Behaviour

25. Ilesanmi, SO (1997) 'Civil-Political Rights or Social Economic Rights for Africa? A Comparative Ethical Critique of a False Dichotomy' 17 The Annual of the Society of Christian Ethics

26. Imam, I (2015) 'Judicial Activism in Nigeria: Delineating the Extend of Legislative-judicial Engagement in Law Making' 15(1) International and Comparative Law Review, 109-127 ICLR Palacký University Olomouc, Czech Republic.

27. Internet Encyclopedia of Philosophy. https://www.iep.utm.edu/soccont/ accessed on 25082019

28. Irons, P (1988) 'Making Law: The Case for Judicial Activism' 23 Val. U. L. Rev. 35. Available at: http://scholar.valpo.edu/vulr/vol23/iss1/2 accessed 29082019

29. Jaichand, V (2004) 'Public Interest Litigation Strategies for Advancing Human Rights in Domestic Systems of Law' 1(1) Sur - International Journal on Human Rights 126-141

30. Khatthewale, MH (2016) Public Interest Litigation https://www.slideshare.net/moulahussainkhatthewale/public-interestlitigation-68893018. Accessed on 28082019

31. Khosa, S (2007) 'Socio-Economic Rights in South Africa: A resource book'

32. Kobani, D; Nkpolu-Oroworukwo (2014) 'The Impact of Girl-Child Education on Community Development: A Study of Ika Local 
Government Area of Akwa Ibom State' 4(12) Research on Humanities and Social Sciences

33. Leicht, A; Heiss, J and Byun, WJ (eds) (2018) 'Issues and trends in education for sustainable development' UNESCO Publishing France.

34. Marks, SP (2014) 'Human Rights: A Brief Introduction' Working Paper, Harvard School of Public Health. At https://dash.harvard.edu/bitstream/handle/1/23586712/Human\%20Ri ghts-A\%20Brief\%20Introduction,\%202014\%20ed.pdf? sequence=1 accessed 30 August 2019

35. Mshelbila, ED (2012) 'Girl-Child/Women Education for Sustainable Development in Nigeria' 4 Journal of Education and Leadership Development 35.

36. Nmadu, G; Avidime, S; Oguntunde, O; Dashe, V; Abdulkarim, B; Mandara, M (2010) 'Girl Child Education: Rising to the Challenge' 14 (3) African Journal of Reproductive Health (Special Issue)

37. Nwatu, SI "Legal Framework for the Protection of Socio-Economic Rights in Nigeria" 10 Nig. J. R Nigerian Juridical Review (2011-2012) 23

38. Ocho, L. O. (2005) 'National development and the curriculum' in Oriaifo, S.O. Edozie, G.C.; \& Ezeh, D.N. (eds.), Curriculum issues in contemporary Education. Benin City: Da Sylra.

39. Okeke, GN and Okeke, C (2013) 'The justiciability of the nonjusticiability of constitutional policy of governance in Nigeria' IOSR Journal of Humanities and Social Science (IOSR-JHSS)9-14

40. Okoroma, NS (2006) 'Educational policies and problems of implementation in Nigeria' 46(2) Australian Journal of Adult Learning

41. Olowu, D (2017) 'Province of Law, Society and Development' Kraft Books Limited, Ibadan 17

42. Olowu, D (2009) 'An Integrative Right based approach to human development in Africa' Pretoria University Law Press

43. Omede, AA; Agahiu, GE (2016) 'The Implications of Girl-Child Education to Nation Building in the $21^{\text {st }}$ Century in Nigeria' $16(3)$ Global Journal of HUMAN-SOCIAL SCIENCE: G Linguistics \& Education

44. Oruonye, ED (2012) 'The Challenges of Girl-Child Education to the Attainment of the Millennium Development Goals in Taraba State Nigeria' 2(1) TSU Journal of Arts and Social Sciences

45. Phillips, D 'Saving the Nigerian Girl Child' Department of Mass Communication, Bayero University, Kano. On February 21, 2019 https://www.vanguardngr.com/2019/02/saving-the-nigerian-girlchild/ 
46. Shehu, AT (2013) 'The Enforcement of Social and Economic Rights in Africa: The Nigerian Experience' 2(1) Afe Babalola University: Journal of Sustainable Development Law and Policy

47. Skenderaj, M (2015) 'Law, Rights, and Justice: The Defence of Human Rights and Freedom' 11(34) European Scientific Journal 465.

48. Symington, A; Gokal S \& Principe, T (2006) 'Achieving Women's Economic \& Social Rights Strategies and Lessons from Experience' Association for Women's Rights in Development Canada.

49. Temidayo, M (2013) 'Social change through public interest litigation' http://www.yourcommonwealth.org/uncategorized/social-changethrough-public-interest-litigation accessed on 28082019

50. Tyoakaa, LM; Amaka, JI; Nor, (2014) 'A Problems and Challenges of Girl-Child Education in Nigeria: The Situation of Kalgo Local Government Area (L.G.A) Of Kebbi State' IOSR Journal of Research \& Method in Education (IOSR-JRME).

51. WHO 2002 World report on violence and health: summary page $\mathrm{v}$ 